\title{
S5ynthesis
}

International Scientific Conference of IT and Business-Related Research

\section{EMISIJA ZAGAĐUJUĆIH MATERIJA I PRIMENA GIS - A}

\section{POLLUTANT EMISSIONS AND GIS APPLICATION}

\author{
Milan Stojanović ${ }^{1}$, Dušan Regodić ${ }^{2}$, Verka Jovanović ${ }^{2}$ \\ ${ }^{1}$ Univerzitet Singidunim, Danijelova 32, Beograd, Srbija \\ ${ }^{2}$ Univerzitet Singidunim, Danijelova 32, Beograd, Srbija
}

\begin{abstract}
Apstrakt:
Ljudi su najveći zagađivači životne sredine, a problemi koji se javljaju zbog zagađenja životne sredine najčešće su povezani sa zagađenjem vazduha. Najčešći i najrasprostranjeniji zagađivači vazduha su vozila u drumskom saobraćaju. Cilj ovog rada jeste razvoj sistema za podršku odlučivanju, koji mogu koristiti nadležni organi za smanjenje zagađenja vazduha koje potiče iz drumskog saobraćaja. Prilikom koncipiranja ovog rada korišćeni su podaci iz pravilnika o podeli motornih i priključnih vozila i tehničkim uslovima za vozila u saobraćaju na putevima, zatim podaci iz elektronske publikacije "Brojanje saobraćaja na putevima Republike Srbije u 2009. godini”, koju je izdalo JP Putevi Srbije, podaci iz izveštaja Republičkog zavoda za statistiku i podaci iz izveštaja Republičkog hidrometeorološkog zavoda. Ulazni podaci emisionog modela bili su: tok saobraćaja na deonicama auto-puta Beograd-Niš, broj vozila prema tehnologiji, emisioni faktori i matematičke operacije COPERT IV metodologije, kao i podaci o potrošnji goriva. Podaci o vozilima predstavljeni su i u projektu Instituta Saobraćajnog fakulteta, Univerziteta u Beogradu.
\end{abstract}

\section{Ključne reči:}

zagađujuće materije, COPERT IV metodologija, simulacija distribucije, GIS.

\section{UVOD}

Čovek je deo životne sredine i njen najveći zagađivač. On svojim aktivnostima oblikuje životnu sredinu prema svojim potrebama, utičući na njen kvalitet, pri čemu narušena životna sredina postaje ograničavajući faktor razvoja i blagostanja ljudi. Poslednjih decenija raste zabrinutost ljudi za kvalitet životne sredine, jer je njen kvalitet jedan od bitnih faktora rizika za nastanak različitih bolesti.

Problemi koji se javljaju zbog zagađenja životne sredine najčešće su povezani sa zagađenjem vazduha. Pored statičnih postoje i mobilni izvori zagađenja vazduha. Najčešće se u kontekstu mobilnih izvora zagađenja misli na motorna vozila u drumskom saobraćaju. Emisija iz motornih vozila utiče na prostorno rasprostiranje izduvnih gasova, suspendovanih čestica i povećanu koncentraciju toksičnih materija u urbanim sredinama.

Predmet istraživanja ovog rada usredsređen je na izradu i implementaciju GIS-a (Geographic Information System) u kontrolnoj strategiji monitoringa ukupne emisije zagađujućih materija u drumskom saobraćaju.

Zagađenje vazduha koje izazivaju motorna vozila jedan je od najozbiljnijih problema današnjeg civilizovanog društva. Cilj ovog rada je razvoj sistema za podršku odlučivanju koji će koristiti nadležni organi, da bi se smanjilo zagađenje vazduha koje nastaje u automobilskom saobraćaju.

\section{Abstract:}

Humans are the largest environmental pollutants, and the issues caused by environmental pollution are mostly connected with air pollution. The most common and most widespread air pollutants are road transport vehicles. The aim of this paper is to develop decision support systems, which can be used by the authorities to reduce air pollution from road transport. Research was based on the data from the Regulations on the classification of motor and towed vehicles and technical conditions for the vehicles in road transport, the electronic publication "Counting motor vehicles on the roads of Republic of Serbia in 2009.", published by the public enterprise Roads of Serbia, the Republic Institute of Statistics, and the Republic Hydrometeorological Service. The input data of the emission model included: traffic flow on the sections of Belgrade-Niš highway, number of vehicles classified according to technology, emission factors and mathematical operations of COPERT IV methodology, and fuel consumption. The data on vehicles are also presented within the project of the Institute of the Faculty of Transport and Traffic Engineering, University of Belgrade.

\section{Key words:}

pollutants, COPERT IV methodology, distribution simulation, GIS.

\section{IZBOR METODA PROCENE EMISIJA}

Predmet istraživanja ovog rada usredsređen je na izradu i implementaciju GIS-a (Geographic Information System) u kontrolnoj strategiji monitoringa ukupne emisije zagađujućih materija u drumskom saobraćaju.

Suština ovog sistema se sastoji od brojnih matematičkih podmodela, zasnovanih na postojećoj literaturi, da bi se simulirao model emisije i disperzije zagađujućih materija oslobođenih u saobraćaju na delu autoputa Beograd - Niš. Ovi podmodeli, biće integrisani u GIS, koji koristi prostorne koordinate za opisivanje strukture prostora na razmatranom delu auto-puta. Takođe, dobili bi se podaci o distribuciji zagađujućih materija u prizemnom sloju atmosfere (troposferi).

Tako integrisani GIS ima za cilj da vizuelno prikaže dobijene rezultate emisije i disperzije motornih vozila. Ovi podmodeli biće postavljeni u kaskadnom obliku, pri čemu će se karakteristike saobraćaja koristiti kao ulazni podaci za proračun emisije, dok bi rezultati emisije bili ulazni podaci za obračun i simulaciju disperzije zagađujućih materija. Moguće je izvršiti unapređenje procesa kontrole ukupne emisije zagađujućih materija u drumskom saobraćaju korišćenjem GIS-a.

Naime, GIS će, na osnovu podataka koji se unose u njegovu bazu podataka, omogućiti selektovanje tzv. kritičnih gridova, odnosno oblasti na kojima je najveće zagađenje. Tako bi se došlo 
do informacija koje su neophodne za preduzimanje adekvatnih mera u cilju smanjenja zagađenja vazduha na tom području. Moguće je izvršiti unapređenje procesa kontrole ukupne emisije zagađujućih materija u drumskom saobraćaju korišćenjem GIS-a.

Za uspešnu realizaciju ciljeva istraživanja, obradu i dokazivanje postavljenih hipoteza u ovom radu koristiće se osnovne i posebne metode logičkog rasuđivanja i naučnog saznanja, a pored njih i specijalne naučne metode, kao što su:

COPERT IV metoda, za proračun emisije zagađujućih materija. COPERT IV je jedan od najčešće korišćenih softverskih alata za određivanje količine emitovanih zagađujućih materija koje potiču iz motornih vozila, uzimajući u obzir navedene propise. Korišćenje ovog softverskog alata omogućava izradu baza podataka i procedura izveštavanja o emisiji zagađujućih supstanci, koji su u sagalasnosti sa međunarodnim sporazumima i zakonodavstvom EU. COPERT IV metodologija se koristi za proračunavanje regularnih (CO, NOx, VOC, PM) (Konsolidou et al., 2008, str. 7468) i neregularnih zagađujućih materija $\left(\mathrm{N}_{2} \mathrm{O}\right.$, $\mathrm{NH}_{3}, \mathrm{NMVOC}$ i slično), kao i proračun potrošnje goriva.

Metoda simulacije distribucije emisije zagađujućih materija. Uopšteno, proces simulacije se sastoji iz dve osnovne faze: faze izgradnje modela i faze eksperimentisanja na modelu uz analizu dobijenih rezultata. Obe ove faze uključuju mnoge aktivnosti, koje su podjednako važne za uspešno izvršavanje simulacije.

Model sistema predstavlja uprošćenu i apstraktnu sliku realnog sistema, odnosno model je opis realnog sistema sa svim njegovim karakteristikama koje su relevantne iz ugla posmatranja pojedinca ili grupe koja se bavi simulacijom. Simulacija distribucije emisije zagađujućih materija urađena je uz primenu softverskog alata AQRoads (Air Quality Roads). AQRoads je softverska aplikacija sa grafičkim korisničkim interfejsom koja se koristi za proračun emisije zagađujućih materija u drumskom saobraćaju i simulaciju atmosferske disperzije preko dvodimenzionalnog domena.

Analitička metoda GIS-a. GIS je sistem za upravljanje prostornim podacima i njihovim osobinama. U širem smislu to je sistem koji korisnicima daje mogućnost da postavljaju interaktivne upite, analiziraju prostorne informacije i uređuju podatke. GIS čine četiri interaktivna podsistema: (Čekerevac et al., 2010, str. 533) podsistem za unos koji vrši tzv. digitalizaciju podataka, podsistem za skladištenje i povezivanje podataka, podsistem za analizu, i izlazni podsistem za izradu karata, tabela i dobijanje odgovora na postavljene upite. GIS je jedna velika baza podataka u kojoj su geografske lokacije snimljene kao matematičke koordinate, a informacije o lokaciji su smeštene u tabelama koje su povezane sa lokacijom.

Radi formiranja i primene GIS modela u kontrolnoj strategiji monitoring ukupne emisije zagađujućih materija biće korišćen, kao model-sistem, auto-put Beograd-Niš, pri čemu će biti upotrebljeni sledeći izvori podataka:

1. Sekundarni izvori: Pravilnik o podeli motornih i priključnih vozila i tehničkim uslovima za vozila u saobraćaju na putevima (Službeni glasnik RS, br. 54/2010 i 69/2010), izveštaji iz Republičkog zavoda za statistiku, izveštaji iz Hidrometeorološkog zavoda, te podaci iz elektronske publikacije „Brojanje saobraćaja na putevima Republike Srbije u 2009. godini”.

2. Kartografski podaci: mapa Republike Srbije - magistralna i regionalna putna mreža $(1: 1.300 .000)$ Državni putevi I i II reda, (Putevi Srbije, 2015) i topografska mapa auto-puta Beograd-Niš (1:100.000) (Topografske karte Republike Srbije u razmeri 1:100000).

\section{REZULTATI I DISKUSIJA}

Put Beograd - Niš je deo autoputa E-75. Ovaj put nema oštrih krivina, odnosno pogodan je za brzine od najmanje 80 $\mathrm{km} / \mathrm{h}$, ima četiri vozne trake, dve zaustavne trake, dve ivične trake, jednu razdelnu traku i dve zemljane bankine, čime ispunjava tehničke karakteristike auto-puta. Kapacitet saobraćaja na ovom putu je veliki i zbog toga su izbegnute saobraćajne gužve, odnosno ne prolazi se kroz naseljena mesta, već u njihovoj blizini, što je još jedna od karakteristika koja ukazuje na činjenicu da je taj model saobraćaja karakterističan za auto-puteve.

Za proračun emisije izduvnih gasova korišćeni su podaci o voznom parku Republike Srbije, podaci o protoku vozila na autoputu Beograd-Niš, kao i emisioni faktori iz softverskog alata COPERT 4. Podaci o vozilima su prikupljeni iz Republičkog zavoda za statistiku i Ministarstva unutrašnjih poslova, a za potrebe proračuna emisije korišćeni su i podaci o meteorološkim parametrima, preuzeti iz Republičkog hidrometeorološkog zavoda Srbije (Institut saobraćajnog fakulteta, 2010, str. 4).

Da bi podaci o vozilima mogli da se koriste za COPERT IV softver bilo je potrebno da se postojeća kategorizacija vozila prilagodi kategorizaciji vozila u COPERT IV modelu. U evidenciji registrovanih vozila Republike Srbije su prisutne sledeće kategorije: putnički automobili, teretna vozila, vučna vozila, kombi, specijalna, odnosno radna vozila, autobusi i motocikli.

Kategorizacija koja je potrebna da bi se obavio unos podataka za proračun uključuje sledeće grupe vozila: putničke automobile, laka teretna vozila, teška teretna vozila, autobuse, mopede i motocikle.

Vrste goriva koje se nalaze u evidenciji registrovanih vozila su: benzin 98 , benzin 86 , dizel, mešavina benzin-gas i električna energija. Kategorizacija prema vrsti goriva, koja je potrebna za unos u bazu podataka koju koristi softverski alat uključuje: benzin koji sadrži olovo, bezolovni benzin, dizel, TNG, hibrid i KPG.

Svaka kategorija vozila iz evidencije registrovanih vozila ima posebne karakteristike, odnosno uslove prema kojima se vozila grupišu. Kod putničkih automobila grupisanje pogonskog goriva izvršeno je na sledeći način: benzin 98 i benzin 86 svrstani su pod benzin; od ukupnog broja putničkih automobila sa pogonom na benzin sva proizvedena od 1992. godine svrstana su pod PA sa pogonom na benzin koji sadrži olovo; putnički automobili marke i tipa Zastava 10 svrstani su pod PA sa pogonom na benzin koji sadrži olovo; pogonsko gorivo mešavina i električna energija podeljeni su na benzin i dizel, tako što se prema marki i tipu vozila odredilo da li je vozilo sa pogonom na benzin ili dizel; benzin - gas svrstan je pod TNG; električna energija je svrstana pod benzin.

Vozila su grupisana po zapremini motora, a s obzirom na to da podaci za određeni broj vozila nisu adekvatni korekcija tih vrednosti je izvršena u toku pregleda evidencije. Zatim su učesnici projekta sa Instituta saobraćajnog fakulteta su primenom odgovarajućeg softvera, koji je razvijen na osnovu postavljenih kriterijuma, izvršili grupisanje vozila prema zapremini motora (Institut saobraćajnog fakulteta, 2010, str. 7).

Za potrebe proračune emisije primenom softverskog alata COPERT IV, na deonici Beograd-Tranšped autoputa Beograd-Niš, korišćeni su podaci o protoku vozila na 20 deonica tog autoputa, koji su preuzeti iz elektronske publikacije koju je objavilo JP Putevi Srbije.

Ovi podaci su iskorišćeni za grupisanje vozila po kategorijama koje zahteva pomenuti softverski alat tako što su podaci iz elektronske publikacije, prema kojima su vozila grupisana u četri kategorije, procentualno grupisani u odnosu na ukupan 
broj registrovanih vozila prema kategorijama koje zahteva softverski alat COPERT IV. U narednoj tabeli, prikazan je broj vozila po tehnologiji na deonici Beograd - Tranšped autoputa Beograd-Niš.

$\mathrm{Na}$ osnovu podataka o vozilima, kao i podataka o potrošnji goriva i meteoroloških podataka, odnosno podataka o minimalnim i maksimalnim vrednostima temperature vazduha po mesecima, koji su uneti u bazu podataka korišćenog programskog paketa COPERT IV, dobijeni su podaci o potrošnji goriva i ukupnoj emisiji zagađujućih materija u 2009. godini. Podatke ćemo prikazati u narednoj tabeli.

Analiza ukupne emisije zagađujućih materija prema izvorima zagađenja po deonicama auto-puta Beograd-Nišs, što ćemo prikazati narednim tabelama.

\begin{tabular}{|c|c|c|c|c|c|}
\hline $\begin{array}{l}\text { Vozila po } \\
\text { tehnologiji }\end{array}$ & $\begin{array}{l}\text { Ukupan broj } \\
\text { vozila }\end{array}$ & Vozila po tehnologiji & $\begin{array}{l}\text { Ukupan broj } \\
\text { vozila }\end{array}$ & $\begin{array}{l}\text { Vozila po teh- } \\
\text { nologiji }\end{array}$ & $\begin{array}{l}\text { Ukupan broj } \\
\text { vozila }\end{array}$ \\
\hline Benzin $<1.4 \mathrm{t}$ & & EURO 2 & 5805 & autobus $15-18 \mathrm{t}$ & \\
\hline PRE ECE & 17429 & EURO 3 & 22105 & konvencionalna & 18992 \\
\hline ECE $15 / 00-01$ & 98155 & $\begin{array}{c}\text { Četvorotaktni motocikli } \\
250-750 \mathrm{~cm}^{\wedge} 3\end{array}$ & & EURO 1 & 2839 \\
\hline ECE $15 / 02$ & 133014 & konvencionalna & 23788 & EURO 2 & 4081 \\
\hline ECE 15/03 & 523801 & EURO 1 & 4178 & EURO 3 & 18671 \\
\hline ECE 15/04 & 1838350 & EURO 2 & 3966 & EURO 4 & 6449 \\
\hline EURO 1 & 243095 & EURO 3 & 7220 & EURO 5 & 386 \\
\hline EURO 2 & 411886 & $\begin{array}{c}\text { Četvorotaktni } \\
\text { motocikli }>750 \mathrm{~cm}^{\wedge} 3\end{array}$ & & autobusi $<=18 \mathrm{t}$ & \\
\hline EURO 3 & 569668 & konvencionalna & 8056 & konvencionalna & 31322 \\
\hline EURO 4 & 565082 & EURO 1 & 2195 & EURO 1 & 3846 \\
\hline Benzin 1.4-2t & & EURO 2 & 2585 & EURO 2 & 4638 \\
\hline PRE ECE & 7339 & EURO 3 & 4713 & EURO 3 & 8784 \\
\hline ECE 15/00-01 & 14677 & Benzin $<3.5 t$ & & EURO 4 & 5934 \\
\hline ECE 15/02 & 33942 & konvencionalna & 11036 & EURO 5 & 1178 \\
\hline ECE 15/03 & 215575 & EURO 1 & 1348 & $20-26 \mathrm{t}$ & \\
\hline ECE 15/04 & 682501 & EURO 2 & 521 & konvencionalna & 9735 \\
\hline EURO 1 & 205484 & EURO 3 & 575 & EURO 1 & 3026 \\
\hline EURO 2 & 357763 & EURO 4 & 139 & EURO 2 & 5657 \\
\hline EURO 3 & 446745 & Dizel $<3.5 \mathrm{t}$ & & EURO 3 & 7565 \\
\hline EURO 4 & 166039 & konvencionalna & 18351 & EURO 4 & 1776 \\
\hline Benzin $>2 t$ & & EURO 1 & 5136 & EURO 5 & 132 \\
\hline PRE ECE & 826 & EURO 2 & 3303 & $26-28 \mathrm{t}$ & \\
\hline ECE 15/00-01 & 1468 & EURO 3 & 3244 & konvencionalna & 10261 \\
\hline ECE 15/02 & 3027 & Benzin $<=7.5 t$ & & EURO 1 & 3092 \\
\hline ECE $15 / 03$ & 12843 & konvencionalna & 119962 & EURO 2 & 5657 \\
\hline ECE 15/04 & 44032 & EURO 1 & 36754 & EURO 3 & 7696 \\
\hline EURO 1 & 22016 & EURO 2 & 66178 & EURO 4 & 1776 \\
\hline EURO 2 & 31190 & EURO 3 & 92801 & EURO 5 & 132 \\
\hline EURO 3 & 44950 & EURO 4 & 20371 & $28-32 t$ & \\
\hline EURO 4 & 22934 & EURO 5 & 1293 & konvencionalna & 18286 \\
\hline Dizel $<2 \mathrm{t}$ & & $7.5-12 \mathrm{t}$ & & EURO 1 & 6380 \\
\hline konvencionalna & 632965 & konvencionalna & 69412 & EURO 2 & 11511 \\
\hline EURO 1 & 129345 & EURO 1 & 21341 & EURO 3 & 16116 \\
\hline EURO 2 & 246765 & EURO 2 & 38263 & EURO 4 & 3552 \\
\hline EURO 3 & 571503 & EURO 3 & 53783 & EURO 5 & 263 \\
\hline EURO 4 & 366936 & EURO 4 & 11748 & $>-32 t$ & \\
\hline Dizel $>2 t$ & & EURO 5 & 754 & konvencionalna & 165104 \\
\hline konvencionalna & 49536 & $12-14 \mathrm{t}$ & & EURO 1 & 47821 \\
\hline EURO 1 & 18530 & konvencionalna & 55185 & EURO 2 & 91629 \\
\hline EURO 2 & 27520 & EURO 1 & 17030 & EURO 3 & 127413 \\
\hline EURO 3 & 57792 & EURO 2 & 30395 & EURO 4 & 28219 \\
\hline EURO 4 & 45867 & EURO 3 & 40742 & EURO 5 & 1842 \\
\hline TNG & & EURO 4 & 9700 & $34-40 t$ & \\
\hline konvencionalna & 173377 & EURO 5 & 647 & konvencionalna & 27561 \\
\hline EURO 1 & 26603 & $14-20 \mathrm{t}$ & & EURO 1 & 9538 \\
\hline EURO 2 & 44950 & konvencionalna & 137530 & EURO 2 & 13353 \\
\hline EURO 3 & 35776 & EURO 1 & 39772 & EURO 3 & 20720 \\
\hline EURO 4 & 32107 & EURO 2 & 78466 & EURO 4 & 11051 \\
\hline $\begin{array}{c}\text { Četvorotaktni } \\
\text { motocikli }<250 \mathrm{~cm}^{\wedge} 3\end{array}$ & & EURO 3 & 110046 & EURO 5 & 921 \\
\hline konvencionalna & 17559 & EURO 4 & 24035 & & \\
\hline EURO 1 & 9248 & EURO 5 & 1617 & & \\
\hline
\end{tabular}

Tabela 1. Ukupan broj vozila po tehnologiji na deonici Beograd - Tranšped 
Na osnovu prikazanih podataka može se uočiti da najveća emisija zagađujućih materija potiče iz putničkih vozila i teških teretnih vozila. $U$ tom smislu, integracija kontrolnih sistema saobraćaja kao i podaci o uticaju motornih vozila na zagađenje životne sredine, bili bi od velikog značaja za unapređenje baze podataka o emisiji zagađujućih materija.

Mnoge studije monitoringa kvaliteta vazduha koje se sprovode blizu glavnih saobraćajnica beleže koncentracije zagađujućih materija koje potiču iz motornih vozila, a odnose se na CO, NOx, PM, itd. Rezultati kontrole kvaliteta vazduha, kao i studije kojima se ispituje uticaj kvaliteta vazduha na zdravlje ljudi, podstakli su istraživanje koje je sprovela US EPA da bi se definisao uticaj emisije koja potiče iz saobraćaja na vremensku i prostornu varijabilnost koncentracija zagađujućih materija u životnoj sredini blizu saobraćajnica. Jedan od ciljeva ove studije bila je procena postojećih emisija i modeli disperzije za područja blizu glavnih saobraćajnih puteva (Venkatram et al., 2007, str. 9490).

Da bi se definisao GIS model za potrebe monitoringa ukupne emisije zagađujućih materija korišćen je softverski alat MapWindow GIS (verzija 4.8.1). Radi prikazivanja nekih osnovnih tematskih mogućnosti GIS-a, na narednim slikama prikazani su izlazni rezultati integrisanih modela saobraćaja, emisije i disperzije zagađujućih materija. GIS je korišćen za povezivanje prostornih podataka sa odgovarajućim atributnim alfanumeričkim podacima. Ovaj model, kao i svaki GIS model, podrazumeva nekoliko slojeva koji sadrže prostorne podatke.

Posle unošenja prvog sloja, odnosno topografske mape auto-puta Beograd-Niš urađeno je georeferenciranje mape (Slika
1) da bi koordinate sa mape bile usklađene sa realnim koordinatama, odnosno primenjenim geografskim koordinatnim sistemom (UTM Zona 34N) koji se koristi u Srbiji.

Tek kada se uradi georeferenciranje mape koja je osnova za kreiranje GIS modela, pristupa se unošenju drugih slojeva. Takođe, bitno je za svaki sloj, koji se sastoji od određenih vektorskih oblika, da ima određen koordinatni sistem koji će se primenjivati. On mora biti isti kao i koordinatni sistem koji je izabran za početni sloj, odnosno topografsku mapu autoputa Beograd-Niš.

Pored unošenja grafičkih simbola, GIS zahteva i formiranje baze podataka kroz popunjavanje određenih tabela, pojedinačno za svaki sloj. Na ovaj način korisnicima je omogućen uvid $\mathrm{u}$ atributne alfanumeričke podatke vezane za sve objekte koji su grafički predstavljeni u vidu tačaka, linija ili poligona. Kreiranje baze podataka omogućava zadavanje upita čime se selektuju određeni objekti u tabeli, a istovremeno se vrši njihovo mapiranje na karti.

Slika 2 prikazuje podatke o deonicama. Tabela se sastoji od 9 kolona i 20 redova što znači da su uneti podaci za 20 deonica. U prve dve kolone upisani su identifikacioni brojevi objekata, pri čemu se identifikacioni brojevi u prvoj koloni ne mogu menjati. U trećoj koloni su upisani nazivi deonica, u četvrtoj je upisana dužina svake deonice izražena u kilometrima, u petoj je upisan protok vozila po času na svakoj deonici, u naredne tri kolone upisan je procenat vozila sa pogonom na benzin, dizel i gas (plin), a u poslednjoj koloni upisana je potrošnja goriva po vozilu izražena u litrima. Ovi podaci su dobijeni primenom COPERT IV metodologije.

\begin{tabular}{|c|c|c|c|c|c|}
\hline \multirow{2}{*}{$\begin{array}{l}\text { Zagađujuće } \\
\text { materije }\end{array}$} & \multicolumn{5}{|c|}{ Vrsta vozila } \\
\hline & Putnička vozila & $\begin{array}{c}\text { Laka teretna } \\
\text { vozila }\end{array}$ & $\begin{array}{c}\text { Teška teretna } \\
\text { vozila }\end{array}$ & Autobusi & Motocikli \\
\hline $\mathrm{CO}(\mathrm{t})$ & 469,04 & 4,30 & 34,47 & 2,06 & 25,98 \\
\hline $\operatorname{VOC}(\mathrm{t})$ & 242,26 & 0,80 & 7,89 & 0,51 & 3,08 \\
\hline $\operatorname{NMVOC}(\mathrm{t})$ & 239,64 & 0,79 & 7,19 & 0,47 & 2,87 \\
\hline $\mathrm{CH}_{4}(\mathrm{t})$ & 2,61 & 0,01 & 0,69 & 0,04 & 0,21 \\
\hline $\mathrm{NO}_{x}(\mathrm{t})$ & 216,22 & 1,37 & 155,64 & 10,24 & 0,93 \\
\hline $\mathrm{NO}(\mathrm{t})$ & 202,19 & 1,25 & 137,41 & 9,04 & 0,00 \\
\hline $\mathrm{NO}_{2}(\mathrm{t})$ & 14,03 & 0,12 & 18,23 & 1,20 & 0,00 \\
\hline $\mathrm{N}_{2} \mathrm{O}(\mathrm{t})$ & 0,58 & 0,00 & 0,37 & 0,02 & 0,00 \\
\hline $\mathrm{NH}_{3}(\mathrm{t})$ & 3,50 & 0,00 & 0,08 & 0,00 & 0,00 \\
\hline $\mathrm{PM}_{2.5}(\mathrm{t})$ & 4,15 & 0,12 & 4,59 & 0,28 & 0,03 \\
\hline $\mathrm{PM}_{10}(\mathrm{t})$ & 4,49 & 0,12 & 4,84 & 0,29 & 0,03 \\
\hline $\mathrm{PM}_{\text {exhaust }}(\mathrm{t})$ & 3,53 & 0,11 & 4,23 & 0,26 & 0,02 \\
\hline $\mathrm{EC}(\mathrm{t})$ & 2,20 & 0,07 & 2,42 & 0,14 & 0,00 \\
\hline $\mathrm{OM}(\mathrm{t})$ & 1,15 & 0,04 & 1,41 & 0,09 & 0,02 \\
\hline $\mathrm{FC}(\mathrm{t})$ & 7827,47 & 64,39 & 4491,36 & 300,65 & 68,18 \\
\hline $\mathrm{CO}_{2}(\mathrm{t})$ & 24532,63 & 202,81 & 14153,71 & 947,45 & 215,15 \\
\hline $\mathrm{SO}_{2}(\mathrm{t})$ & 1,29 & 0,00 & 0,07 & 0,00 & 0,02 \\
\hline $\mathrm{Pb}(\mathrm{kg})$ & 0,53 & 0,00 & 0,62 & 0,02 & 0,00 \\
\hline Cd (kg) & 0,08 & 0,00 & 0,05 & 0,00 & 0,00 \\
\hline $\mathrm{Cu}(\mathrm{kg})$ & 16,61 & 0,14 & 12,51 & 0,70 & 0,14 \\
\hline $\mathrm{Cr}(\mathrm{kg})$ & 0,56 & 0,00 & 0,45 & 0,02 & 0,00 \\
\hline $\mathrm{Ni}(\mathrm{kg})$ & 0,57 & 0,00 & 0,35 & 0,02 & 0,00 \\
\hline $\mathrm{Se}(\mathrm{kg})$ & 0,09 & 0,00 & 0,05 & 0,00 & 0,00 \\
\hline $\mathrm{Zn}(\mathrm{kg})$ & 12,19 & 0,10 & 7,28 & 0,43 & 0,09 \\
\hline
\end{tabular}

Tabela 2. Ukupna emisija zagađujućih materija prema izvorima zagađenja u 2009. godini na deonici Beograd - Tranšped 


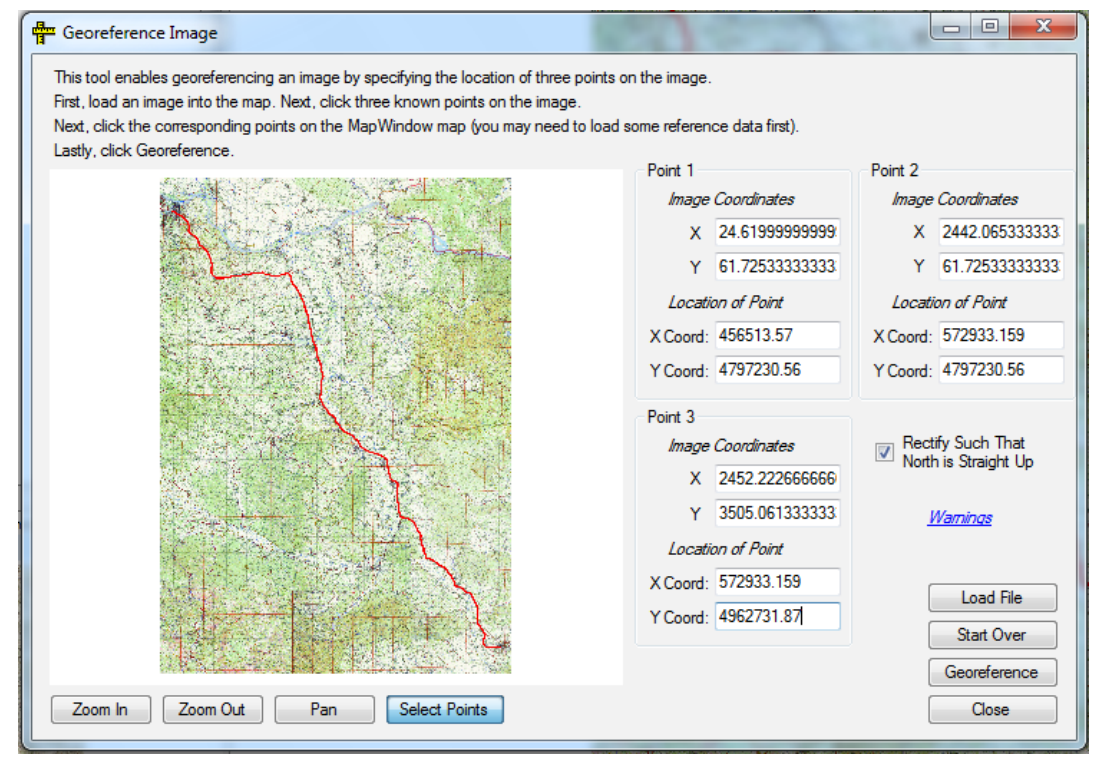

Slika 1. Georeferenciranje topografske mape autoputa

\begin{tabular}{|c|c|c|c|c|c|c|c|c|c|}
\hline \multicolumn{7}{|c|}{ Attribute Table Editor } & \multicolumn{3}{|c|}{\begin{tabular}{|l|l|l|}
0 & 回 & $x$ \\
\end{tabular}} \\
\hline \multicolumn{10}{|c|}{ Edit View Selection Tools } \\
\hline \multirow{2}{*}{\multicolumn{10}{|c|}{ 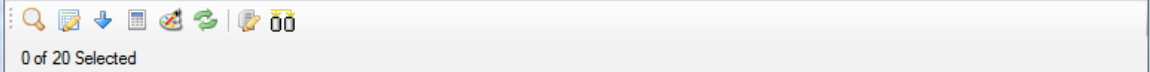 }} \\
\hline & & & & & & & & & \\
\hline \multicolumn{10}{|c|}{ D:IMapWindow GISDeonica.shp } \\
\hline & SHAPE_ID & MWShapelD & Deonica & Duzina(km) & Protok_v/h & $\%$ V(benzin) & $\%$ V(dizel) & $\% \mathrm{~V}(\mathrm{LPG})$ & P.gor/v(l) \\
\hline \multirow[t]{20}{*}{ - } & 0 & 0 & Beograd-Transped & 14.5 & 1275 & 45.2 & 52.66 & 2.14 & 1.141 \\
\hline & 1 & 1 & Transped-Vrcin & 4.4 & 1258 & 45.18 & 52.74 & 2.08 & 0.346 \\
\hline & 2 & 2 & Vrcin-M.Pozarevac & 14.3 & 1141 & 43.86 & 54.07 & 2.07 & 1.146 \\
\hline & 3 & 3 & M.Pozarevac-Umcari & 6.5 & 829 & 41 & 57.06 & 1.94 & 0.543 \\
\hline & 4 & 4 & Umcari-Vodanj & 2.8 & 814 & 40.84 & 57.24 & 1.92 & 0.234 \\
\hline & 5 & 5 & Vodanj-Kolari & 3.1 & 775 & 40.18 & 57.93 & 1.89 & 0.262 \\
\hline & 6 & 6 & Kolari-Smederevo & 11.9 & 761 & 39.93 & 58.18 & 1.89 & 1.009 \\
\hline & 7 & 7 & Smederevo-Pozarevac & 6 & 820 & 38.69 & 59.49 & 1.82 & 0.518 \\
\hline & 8 & 8 & Pozarevac-V.Plana & 28.4 & 687 & 37.51 & 60.73 & 1.76 & 2.499 \\
\hline & 9 & 9 & V.Plana-Markovac & 12 & 700 & 36.61 & 61.67 & 1.72 & 1.071 \\
\hline & 10 & 10 & Markovac-Lapovo & 6.4 & 723 & 37.04 & 61.21 & 1.75 & 0.567 \\
\hline & 11 & 11 & Lapovo-Batocina & 3.8 & 708 & 36.86 & 61.4 & 1.74 & 0.338 \\
\hline & 12 & 12 & Batocina-Jagodina & 21.9 & 618 & 35.94 & 62.37 & 1.69 & 1.973 \\
\hline & 13 & 13 & Jagodina-Cuprija & 12.8 & 573 & 35.61 & 62.71 & 1.68 & 1.161 \\
\hline & 14 & 14 & Cuprija-Paracin & 10.7 & 572 & 35.66 & 62.66 & 1.68 & 0.969 \\
\hline & 15 & 15 & Paracin-Pojate & 12.1 & 540 & 35.67 & 62.65 & 1.68 & 1.096 \\
\hline & 16 & 16 & Pojate-Razanj & 14.7 & 460 & 33.66 & 64.76 & 1.58 & 1.376 \\
\hline & 17 & 17 & Razanj-Al.Rudnici & 18 & 453 & 33.32 & 65.11 & 1.57 & 1.695 \\
\hline & 18 & 18 & Al.Rudnici-Aleksinac & 3.7 & 453 & 33.85 & 64.56 & 1.59 & 0.346 \\
\hline & 19 & 19 & Aleksinac-Nis & 22.8 & 520 & 35.11 & 63.24 & 1.65 & 2.086 \\
\hline & & & & & & & & Apply & Close \\
\hline
\end{tabular}

Slika 2. Tabela atributa sa podacima deoncama

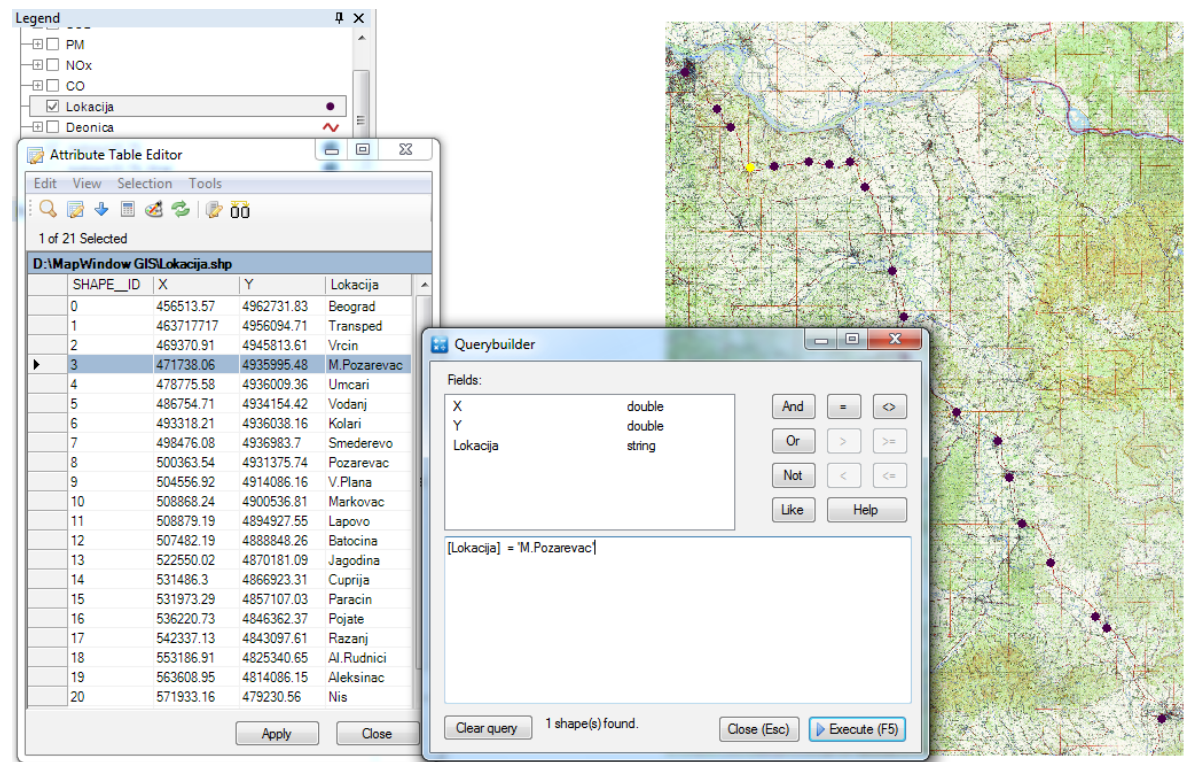




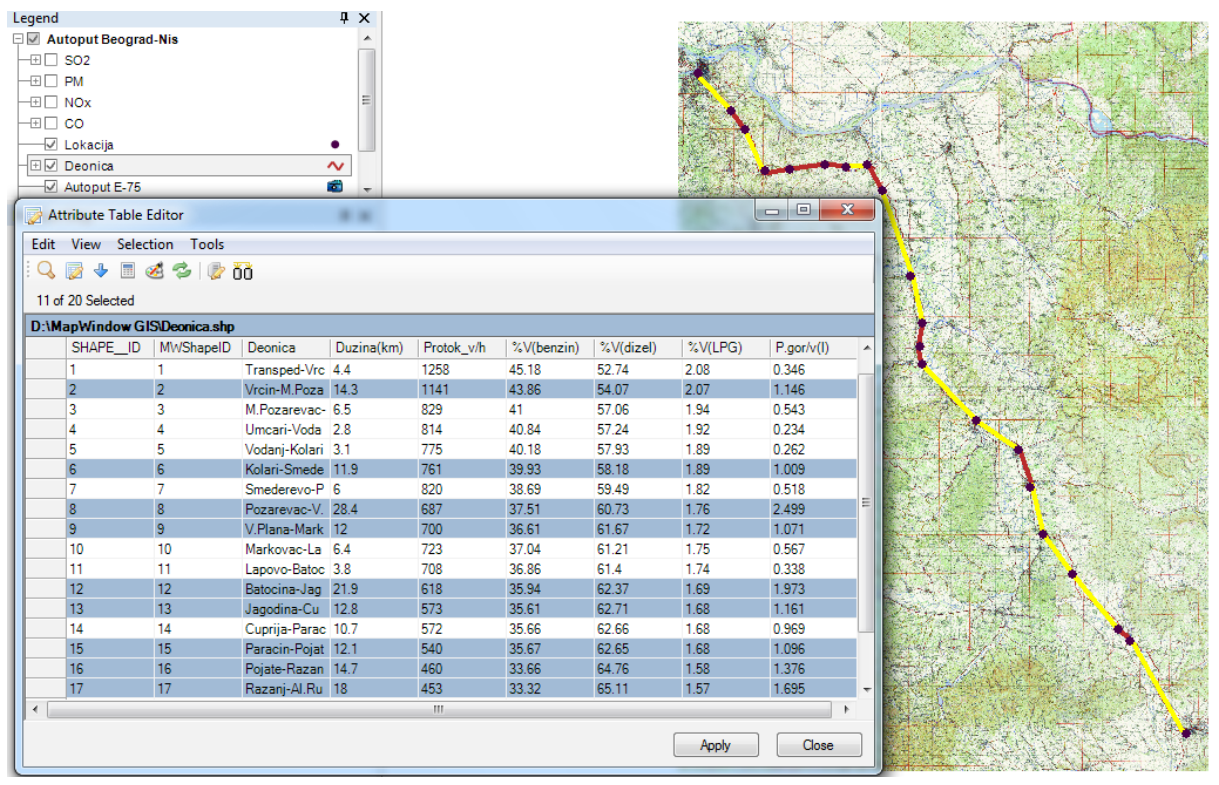

Slika 4. Izbor deonica na kojima je potrošnja goriva po vozilu veća od 1 litar

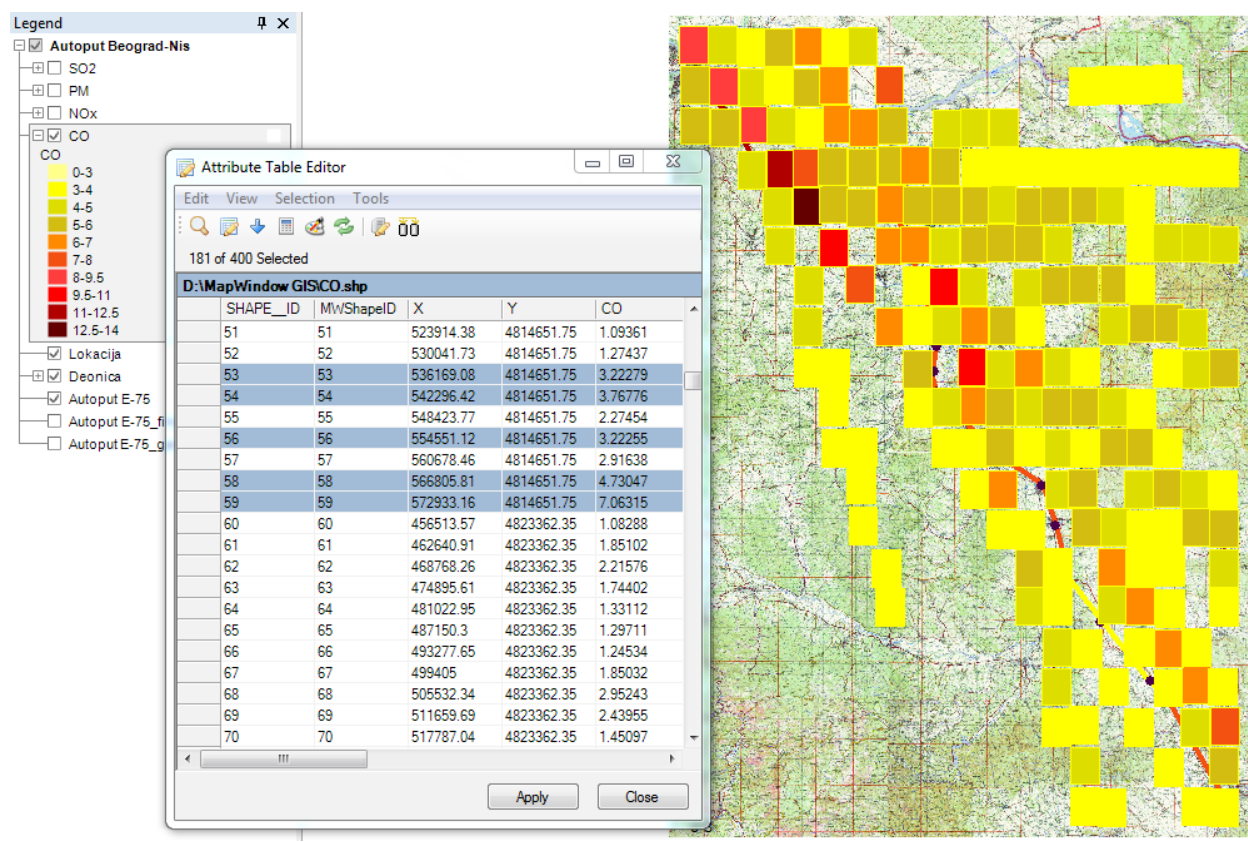

Slika 5. Mapiranje kritičnih gridova sa emisijom CO većom od GVI u slučaju najlošijih vremenskih parametara

Suština primene definisanog modela ogleda se u kreiranju upita. Ako se izabere sloj koji prikazuje mapu auto-puta Beograd-Niš i sloj koji prikazuje lokacije, može se kreirati upit za prikaz lokacije čiji se položaj traži na mapi. Izvršenje tog upita obeležiće lokaciju na mapi, a u tabeli atributa će selektovati sve podatke koji se odnose na traženu lokaciju. Slika 3 prikazuje da je izvršen upit kojim se traži selektovanje lokacije Mali Požarevac. Kao što se može primetiti, selektovana lokacija je markirana žutom bojom, dok su ostale obeležene crnom bojom.

Ako se pored sloja koji prikazuje mapu i sloja sa lokacijama izabere i sloj sa deonicama, dobija se grafički prikaz mape na kojoj su obeležene lokacije i deonice koje povezuju te lokacije. Deonice su obeležene različitom bojom, jer je prilikom kreiranja sloja korišćena opcija za obeležavanje deonica u odnosu na protok vozila po času.

Slika 4 prikazuje selekciju deonica na kojima je potrošnja goriva po vozilu veća od jednog litra. Da bi biranje deonica bilo uočljivije izvršena je korekcija kod obeležavanja deonica tako što je uklonjena opcija za obeležavanje deonica u odnosu na protok vozila po času, pa su sada sve deonice obeležene crvenom bojom. Odabrane deonice markirane su žutom bojom.

Naredni korak predstavlja čekiranje lejera sa gridovima. Prvo će se kreirati upiti za određivanje najzagađenijih, odnosno kritičnih gridova na kojima je emisija CO iznad dozvoljene granice koja za 24 časa iznosi $3 \mathrm{mg} / \mathrm{m}^{3}$, dok za 1 čas iznosi $5 \mathrm{mg} / \mathrm{m}^{3}$.

Tako na primer, Slika 5 prikazuje mapiranje gridova na kojima je emisija CO iznad GVI, odnosno iznad $3 \mathrm{mg} / \mathrm{m}^{3} \mathrm{u}$ slučaju najlošijih meteoroloških uslova, pri čemu je proračun rađen $\mathrm{za}$ brzinu vetra veću ili jednaku $1 \mathrm{~m} / \mathrm{s}$, klasu stabilnosti 4 , kao i za sve pravce vetrova od $0^{\circ}$ do $360^{\circ}$.

$\mathrm{Na}$ osnovu prethodno prikazanih slika na kojima su mapirani gridovi gde je registrovana emisija zagađujućih materija veća od dozvoljenih vrednosti može se zaključiti da je uticaj zadatih meteoroloških parametara na distribuciju emisije zagađujućih materija značajan. Ovaj zaključak se može potkrepiti i rezultatima dobijenih u prethodnim istraživanjima koja ističu prednosti prostorne analize GIS-a pri određivanju kontrolnih gridova u integrisanom modelu GIS-a i linearnog programiranja. 


\section{ZAKLJUČAK}

U radu je prikazana primena GIS modela u kontrolnoj strategiji monitoringa zagađujućih materija u drumskom saobraćaju. Kreiranjem upita dobijeni su precizni podaci koji su prikazani na dva načina: tabelarno i grafički. Naime, u dobijenim tabelama markirani su redovi, a na mapi su markirana kritična područja, odnosno gridovi na kojima su emisije zagađujućih materija bile iznad granica dozvoljenih vrednosti. Klikom na bilo koji kritičan, odnosno markiran grid, dobija se kompletna informacija o tom području. Prema tome, korisnik ovog modela dobija jasniji uvid u dobijeno rešenje zadatog upita što je još jedan dokaz da je GIS najpogodniji za određivanje kontrolnih gridova na kojima treba smanjiti zagađenje.

Cilj upotrebe GIS modela je predobrada i postobrada podataka koji se unose u GIS bazu podataka koja se uvek može dopunjavati i menjati, kao i grafičko prikazivanje (na slojevima) entiteta, odnosno objekata koji su predmet istraživanja i analize. Takođe, osnovna funkcija GIS modela je prezentovanje rezultata koji se dobijaju na osnovu postavljenih upita.

Za razliku od drugih modela, GIS podatke prikazuje na mapi markirajući kritične oblasti što nadležnim organima pruža mogućnost da brže reaguju u preduzimanju adekvatnih mera zaštite životne sredine. Tako je primenom GIS-a moguće izvršiti unapređenje procesa kontrole ukupne emisije zagađujućih materija u drumskom saobraćaju.

Osim toga, GIS pruža mnoge mogućnosti korisniku; pre svega, ovaj sistem omogućava grafičku prezentaciju prostornih objekata na osnovu njihovih atributa, odnosno upravljanje setom atributnih podataka koji se mogu preklasifikovati i integrisati. Među najznačajnijim dostignućima GIS-a je njegova sposobnost da obezbedi modele predviđanja i funkcije koje se bave skladištenim podacima.

GIS analiza omogućava lociranje mesta na kome i zbog čega se pojave dešavaju. Naime, pojavljivanje slučaja se može analizirati na osnovu njihovih međusobnih veza. To omogućava topološka struktura GIS-a što je ponekad prednost za dobijanje nedostupnih inforamcija koje su izvedene iz postojećih.

$\mathrm{Na}$ teritoriji Republike Srbije nije realizovano istraživanje u cilju određivanja kontrolne strategije ukupne emisije zagađujućih materija koje potiču iz drumskog saobraćaja. Sprovođena su samo parcijalna, ograničena istraživanja u toj oblasti, koja daju samo podatke o emisiji. Zbog toga je primena ovog GIS modela $\mathrm{u}$ kontrolnoj strategiji monitoringa ukupne emisije polutanata u drumskom saobraćaju veoma značajna. Kontrolisanje ukupne emisije štetnih supstanci iz izvora zagađenja uz primenu GIS-a znatno je efikasnije. Naime, upotrebom GIS-a dobijaju se vidljivi rezultati (prikazani grafički na mapi) tako da se može brže reagovati u rešavanju evidentiranih problema.

Imajući u vidu navedene činjenice, buduća istraživanja biće vezana za primenu ovog modela u kontrolisanju emisije zagađujućih materija u naseljenim mestima koja imaju probleme sa zagušenjem saobraćaja. Takođe, u planu je primena ovog modela, uz određene modifikacije, u kontrolisanju emisije zagađujućih materija na svim magistralnim i regionalnim putevima Republike Srbije.

\section{LITERATURA}

Čekerevac, Z., Anđelić, S., Glumac, S., \& Dragović, N. (2010). Savremene tendencije primene GIS tehnologija. U:Međunarodna naučna konferencija: Menadžment 2010. 17-18.03. (str. 531 - 538). Kruševac: Fakultet za industrijski menadžment.

Institut Saobraćajnog fakulteta. (2010). Određivanje količina emitovanih gasovitih zagađujućih materija poreklom od drumskog saobraćaja primenom COPERT IV modela Evropske agencije za životnu sredinu. Beograd: Saobraćajni fakultet.

Konsolidou, M., Ntyiachristos, L., Mellios, G., \& Samaras, Z. (2008). Road-transport emission projections to $2020 \mathrm{in} \mathrm{Eu-}$ ropean urban environments. Atmospheric Environment, 42, Amsterdam: Elsevier, pp. 7465-7475.

Putevi Srbije. (2015). Magistralni i regionalni putevi Srbije. Preuzeto 20. marta 2015, sa www.putevi-srbije.rs/pdf/Serbia_ main_and_regional_road.pdf

Topografske karte Republike Srbije u razmeri 1:100000. Preuzeto 20. marta 2015, sa http://mapy.mk.cvut.cz/data/Yugoslavia/ Serbia/Serbia_topo_1.100000 (20.03.2015.)

Venkatram, A., Isakov, V., Thoma, E., \& Baldauf, R. (2007). Analysis of air quality data near road ways using a dispersion model. Atmospheric Environment 41, Amsterdam: Elsevier, pp. 9483-9497. 